\title{
BIOSTIMULÁTOR HATÁSA AZ ÁRVÁCSKA DÍSZÍTŐÉRTÉKÉRE
}

\section{EFFECT OF A BIOSTIMULATOR ON THE DECORATIVE VALUE OF PANSY}

\author{
Turiné Farkas Zsuzsa ${ }^{1^{*}}-$ Palkovics András ${ }^{2}$ - Keringer Kitti ${ }^{3}$ \\ ${ }^{1,3}$ Kertészeti Tanszék, Kertészeti és Vidékfejlesztési Kar, Neumann János Egyetem, Magyarország \\ ${ }^{2}$ Agrárökonómiai és Vidékfejlesztési Tanszék, Kertészeti és Vidékfejlesztési Kar, Neumann János Egyetem, \\ Magyarország \\ https://doi.org/10.47833/2020.3.AGR.009
}

\section{Kulcsszavak:}

árvácska

növénymagasság

kiterjedés

bimbószám

virágszám

\section{Keywords:}

Pansy

plant height

plant expanse

bud count

flower count

\section{Cikktörténet:}

Beérkezett 2020. október 10.

Átdolgozva 2020. október 31.

Elfogadva 2020. november 5

\begin{abstract}
Összefoglalás
Egyik legfontosabb kétnyári dísznövényünk az árvácska. Kutatási munkánkat a Neumann János Egyetem Kertészeti és Vidékfejlesztési Kar Kertészeti Tanszékének termesztőberendezésében végeztük. A palántákat tavaszi értékesitésre állítottuk elő. Munkánk során a növényi ellenálló-képesség fokozására alkalmas Kendal hatását vizsgáltuk az árvácska díszitőértékére. A kutatás során mértük az árvácska morfológiai tulajdonságait: a növénymagasságot, a kiterjedést, a bimbószámot és a virágszámot, avégett, hogy megtudjuk, a Kendal milyen hatást fejt ki e paraméterekre.
\end{abstract}

Abstract
The pansy is one of our most important biennial ornamental
plants. Our research was conducted in the greenhouses of
John von Neumann University, Faculty of Horticulture and Rural
Development, Department of Horticulture. Plugs were grown for
spring sales. We were testing Kendal, which is capable of
strengthening the plant's resistance on the decorative value of
Pansy. We have collected data from the morphological
characteristics of the plant, namely plant height, plant expanse,
bud count and flower count. We wanted to know the effect of
Kendal to these parameters.

\section{Bevezetés}

Napjainkban a nagy virágú árvácskák mellett egyre közkedveltebbé válnak a kis virágúak, melyek nemcsak nagy virág tömegükkel hódítják meg a vásárlókat, de rendkívül ellenállók [1].

A Viola $x$ wittrockiana (kerti árvácska) és a Viola cornuta (szarvas árvácska) botanikájukat tekintve a Violaceae (Ibolyafélék) családjába tartoznak [2].

A kerti árvácska Európából, Közép-Ázsiából származik. Hazánk egyik legismertebb és leggyakrabban használt kétnyári dísznövénye, amelyet az Eurázsiában honos fajok keresztezéses nemesítéséből állítottak elő [3]. A Viola $x$ wittrockiana Delta fajtasorozat az árvácska piacvezető sorozata, egyöntetűségét és habitusát tekintve egyedülálló. A fajtasorozatba tartozó fajták 15-20 cm magasak, jól bokrosodók, nyúlásra nem hajlamosak, ezáltal nem igényelnek intenzív

\footnotetext{
* Corresponding author Email: turine.zsuzsa@kvk.uni-neumann.hu
} 
növekedésszabályozást. Jellemző rájuk a korai virágzási idő, a nagy virágméret és a hatalmas színválaszték, közöttük tisztaszínű illetve szemfoltos fajtákkal $[4 ; 1 ; 5 ; 6]$.

A szarvas árvácska a Pireneusokban őshonos, amely természetes határt képez Spanyolország és Franciaország között [7]. Morfológiai szempontból hasonlítanak a kerti árvácskára, azonban virágaik kisebbek, nem annyira kerekdedek. Mintázatukat tekintve általában egyszínűek, azonban némelyik fajtánál megfigyelhető a szemfoltos, illetve a szakállas mintázat is. Évelöként tartják nyilván, de leggyakrabban egynyári vagy kétnyári növényként termesztik [8]. $A$ Penny sorozat fajtáinak magassága $15-20 \mathrm{~cm}$, virágai kicsik, rengeteg egyedi színnel rendelkező sorozat. Az apró virágok beborítják az egész növényt. Kiválóan alkalmazható őszi és tavaszi kiültetésekbe egyaránt. Kompakt habitusának és erős gyökérzetének köszönhetően jól átteleltethető. Jól alkalmazkodik a meleg időjárási körülményekhez is. A világon a legtöbbet ebböl az árvácska sorozatból értékesítenek [1].

Az árvácska esetében PreNova (előcsíráztatott) vetömagot is forgalmaz a Syngenta FloriPro Services és a GoldsmithSeeds cég. A PreNova vetőmag nagyobb arányú, gyorsabb és egyöntetübb csírázást biztosít, csökken a keléshez szükséges hidegigény, nő a hasznosítható virágpalánta aránya. Egyedülálló technológiánknak köszönhetően a kelésében megindított virág vetőmagot ebben az állapotban konzerválják, így $3-7^{\circ} \mathrm{C}$ - on tárolható 9 hónapig [5].

A tavaszi árvácska fütött és fütetlen körülmények között egyaránt előállítható [9]. Szaporítása többnyire növényházban történik, esetenként fütetlen fóliasátor alatt is termesztik. Magvetéssel szaporítható növényfaj. A vetést kézzel végzik, mely történhet szórva, illetve szemenként. A hagyományos, gyorsabb és kisebb helyigénnyel rendelkező magvetési mód a szórva történő vetés, amely esetében az árvácska magvak vetését szaporító ládákba végzik [10; 11]. Ez esetben tüzdelésre van szükség, amelyet a magvetést követő 2-3 hétben szükséges elvégezni 104 lyukú szaporító tálcába. A korszerübb technológia a szemenkénti vetés, amelyet 104 lyukú szaporító tálcába végeznek. Hátrányai közé tartozik, hogy szaporításához nagyobb területre van szükség a növényházban, azonban a végcserepekbe történő ültetés könnyedén végbemegy a földlabdának köszönhetően, illetve ültetéskor a növények gyökere nem sérül [11]. A biztonságosabb és egyenletesebb kelés érdekében célszerü előcsíráztatott vetőmagot vásárolni. A PreNova kezelés során elöcsíráztatott vetőmagvak az optimálisnál hüvösebb és melegebb hőmérséklet hatására is kiegyenlített kelést eredményeznek, valamint 1-2 nappal lerövidítik a csírázási időt, ezáltal gyors és erőteljes csírázást tesznek lehetővé [6]. A tavaszi árvácska magvetési ideje augusztustól októberig van [5], a palántákat $8-9 \mathrm{~cm}$-es cserépbe ültetik [12; 13; 5]. A cserepezéshez használható: agyag, mikroelemet tartalmazó tartós hatású mütrágya és rostos szerkezetü, 5,5-6,0 $\mathrm{pH}$ - jú tőzeg keveréke [11; 14], vagy 50\% Klasmann Baltica natúr tőzegböl és 50\% Klasmann TS3 típusú földkeverékből összeállított keverék [12; 15]. Az árvácska alacsony tápanyagigényü [11;6].

A növényi biostimulátorok hatékonyabbá teszik a növényben zajló folyamatokat anélkül, hogy megváltoztatnák azokat. A lombozatra vagy a gyökérzónába kijuttatva ösztönzik az élettani folyamatokat, javítják a tápanyagfelvételt és tápanyaghasznosítást, a stresszel szembeni ellenállást és a termés minöségét [16]. A növényi biostimulátorok olyan hatóanyagokat, vagy mikroorganizmusokat tartalmazó készítmények, melyek közvetlenül aktiválják és szabályozzák a gyökér és a gyökérzóna müködését, valamint a növény anyagcsere-folyamatait [17]. A számítógépek, a precíziós technológiák és a drónok világában egyre nagyobb szerepe lesz a hagyományos hozam- és minőségjavító termékeket kiegészítő és felváltó biológiai készítményeknek [18].

A Radifarm készítmény gyorsítja a hajszálgyökerek képződését, gyökérvesztés esetén megújítja a gyökérzetet [19].

A Valagro által kifejlesztett Kendal termékcsalád természetes módon aktiválja a növények külső és belső védekező rendszerét, növeli a termés mennyiségét és minőségét. $A$ készítmény hatására fokozódik a belső védelem és hatékonyabbá válhat a vegyszeres védekezés is. $A$ készítmény müködésének alapja, hogy növeli és gyorsítja a növények aktív védelmi rendszerét, valamint vastagítja a börszövetet és erösíti a lombozatot [20]. Segíti a növényi ellenanyag termelést, használatával jobb kondícióban lehet tartani a növényállományt. Magas kálium tartalma segíti a kompakt növekedést [19]. 


\section{Anyag és módszer}

Publikációnkban a 2018 - 2019. évi kísérletünkről számolunk be.

Kutatási munkánk során a Viola $x$ wittrockiana Delta fajtasorozatba tartozó 'All Colors Mix' színkeverék fajta (PreNova), valamint a Viola cornuta Penny fajtasorozat három F1 fajtájának ('White Jump Up' PreNova, 'Deep Blue', 'White Jump Up') díszítőértékét vizsgáltuk. A kísérletet a Neumann János Egyetem Kertészeti és Vidékfejlesztési Kar Kertészeti Tanszékének Primör-1 típusú fütött üvegházában végeztük. A Delta fajtasorozatba tartozó színkeverék fajta, illetve az egyik 'White Jump Up' fajta esetében előcsíráztatott vetőmagot használtunk. A magvetés 2018. 10. 18 - án történt, kézzel végeztük szemenként, 104 lyukú szaporító tálcába, TS-3 földkeverékbe. A magvetést földkeverékkel takartuk, majd beöntöztük. A csírázásig fóliával takartuk, biztosítva a megfelelő hőmérsékletet és páratartalmat. A palántákat 2019. 01.24 - én $9 \mathrm{~cm}$-es méretű műanyag cserepekbe ültettük. A cserepezés közegeként Klasmann TS-3 földkeveréket használtunk, amelyhez Cropcare 11-11-21 NPK tartalmú műtrágyát kevertünk. Három alkalommal kezeltük a növényeket Radifarm - mal. Első alkalommal a cserepezést követően, majd 2019. 01. 31-én és 2019. 02. 07 - én. 2019. 02.15 - én indult a palánták Kendal - lal történő kezelése, melyet 0,3\%-os töménységben juttattunk ki, majd a kezelést február 22 - én megismételtük. Három kezelést végeztünk: beöntözött formában kijuttatott Kendal, permetezett állapotban kijuttatott Kendal, valamint kontroll (kezeletlen) állomány. Az első Kendal-os kezelés alkalmával a növények tápoldatozását is elkezdtük, amelyet a késöbbiek során, heti gyakorisággal végeztünk. Tápoldatozásra Master 20-20-20 mütrágyát alkalmaztunk 0,2\%-os töménységben. Mindhárom kezelést négy ismétlésben állítottuk be, ismétlésenként négy növénnyel. A három kezelés alkalmával összesen 192 növényt vizsgáltunk. Mértük a növények morfológiai tulajdonságait: a növénymagasságot $(\mathrm{cm})$, a bokor kétirányú átmérőjét $(\mathrm{cm})$, melyböl kiszámítottuk a növények kiterjedését $\left(\mathrm{cm}^{2}\right)$, valamint a virágbimbók és a virágok számát (db/tő). A mérési időpontok: 2019. február 20., február 27., március 6. és március 13. A mért adatokat Excel táblázatban rögzítettük és varianciaanalízis segítségével kiértékeltük.

\section{Eredmények}

Publikációnkban a Viola $x$ wittrockiana Delta fajtasorozatba tartozó 'All Colors Mix' színkeverék fajta (1. ábra) eredményeit mutatjuk be.

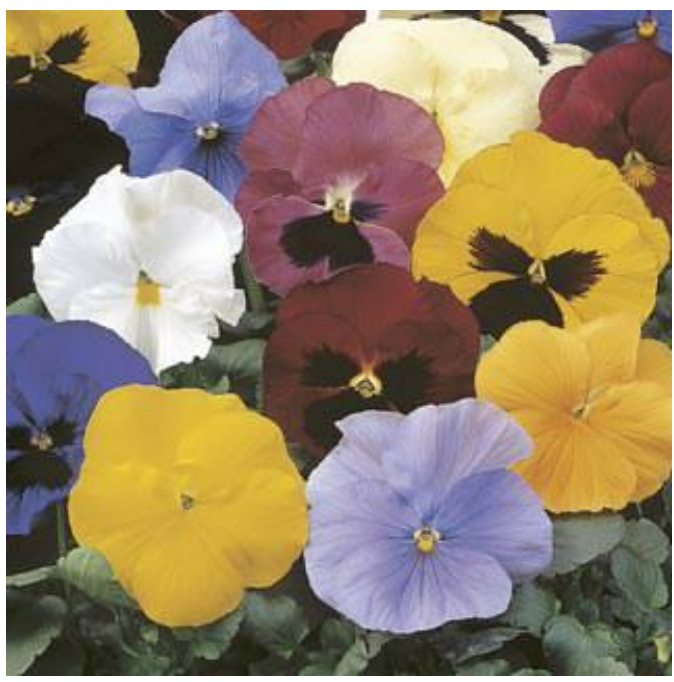

1. ábra. Viola x wittrockiana Delta 'All Colors Mix' 


\subsection{Biostimulátor hatása a Delta fajtasorozat 'All Colors Mix' fajta átlagos növénymagasságára}

A mérési adatok kiértékeléséböl származó eredmények szerint az esetek döntő többségében, így az értékesítésre kész növények utolsó mérési alkalmával is a kontroll állomány eredményezte a legnagyobb növénymagasságot, a permetezett állomány növényegyedei hasonló eredményeket értek el. A beöntözéssel, a növények gyökérzónájába juttatott biostimulátor kezeléssel kaptuk a legalacsonyabb növényeket (2. ábra). Az első mérés alkalmával szignifikáns különbség alakult ki a Delta fajtasorozat 'All Colors Mix' fajta árvácska kontroll (kezeletlen) és beöntözött állománya között (3. ábra). A további mérésekből származó eredmények nem mutattak szignifikáns különbséget az egyes kezelések között.

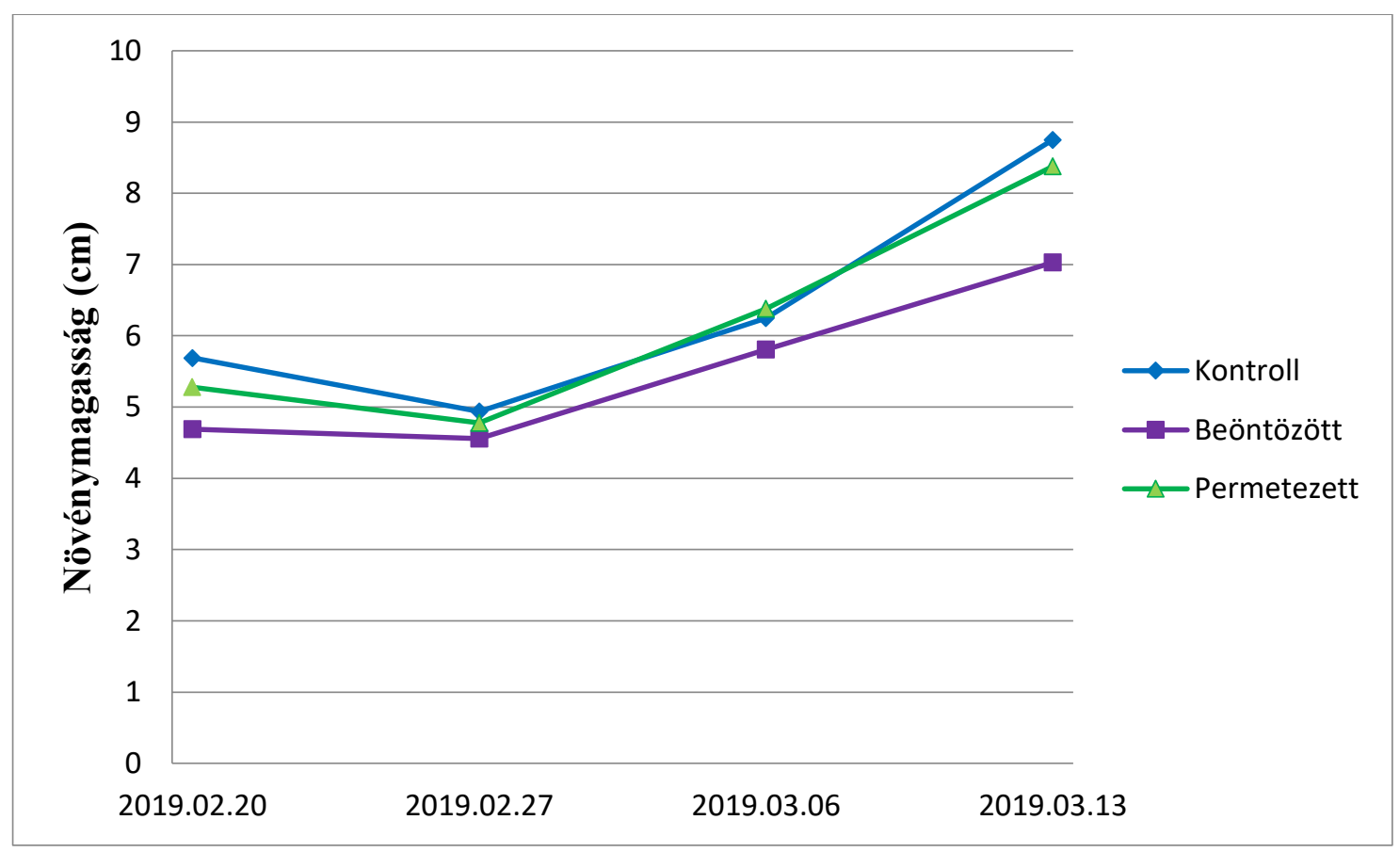

2. ábra. Kendal biostimulátor hatása a Delta fajtasorozat 'All Colors Mix' fajta átlagos növénymagasságára 


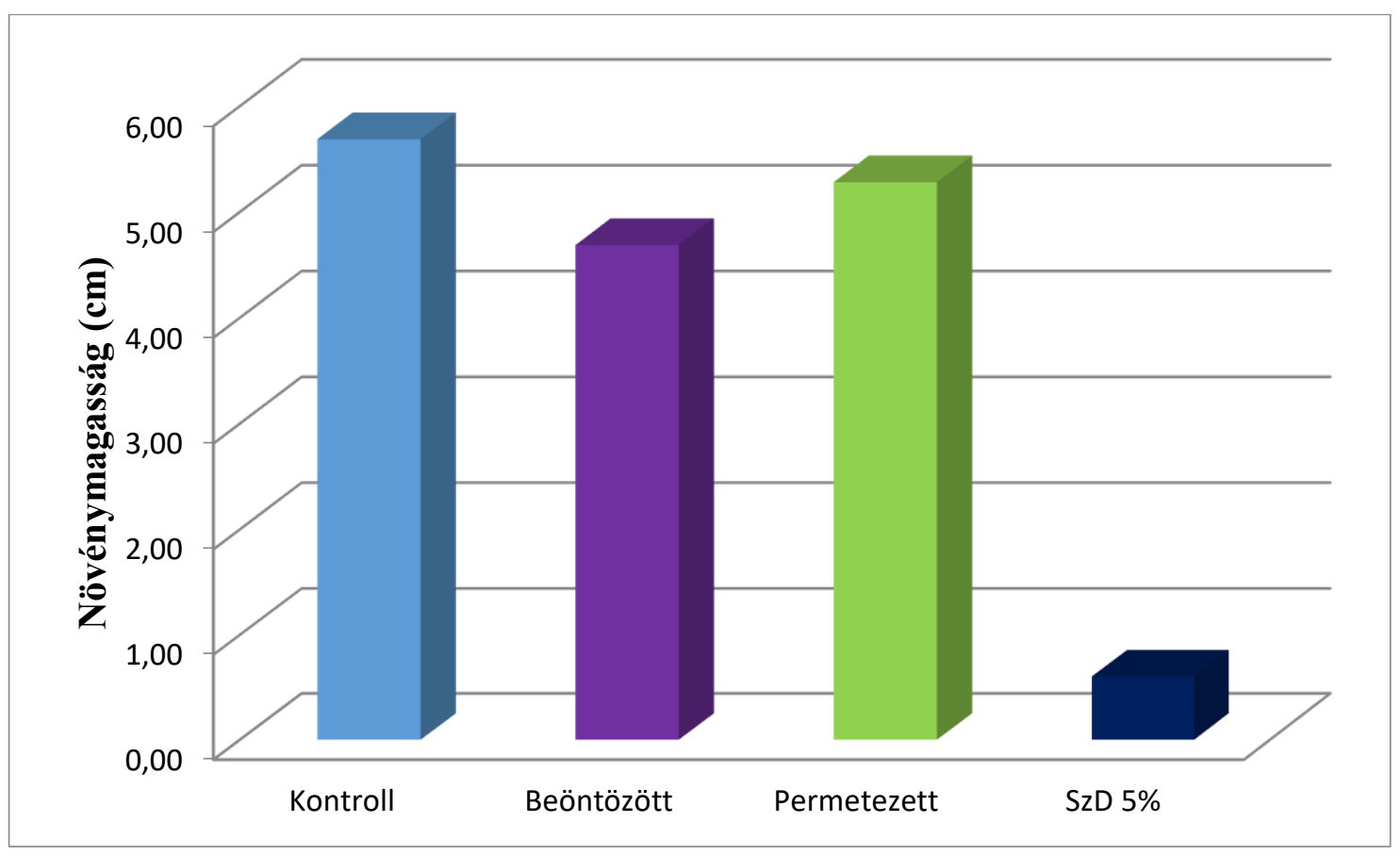

3. ábra. Kendal biostimulátor hatása a Delta fajtasorozat 'All Colors Mix' fajta átlagos növénymagasságára (Kecskemét, 2019. 02. 20.) 


\subsection{Biostimulátor hatása a Delta fajtasorozat 'All Colors Mix' fajta átlagos kiterjedésére}

Általánosságban elmondható, hogy a beöntözéssel kijuttatott biostimulátor kezelés kisebb habitussal rendelkező növényeket eredményezett, ennél nagyobb bokorral rendelkező növényeket kaptunk a permetezett állományban. A kontroll állomány egyedeinek volt a legnagyobb a kiterjedése (4. ábra). A Delta fajtasorozat 'All Colors Mix' fajta átlagos kiterjedése szempontjából a 2. és a 3. mérés alkalmával a kontroll állomány a másik két kezeléshez képest szignifikáns különbséget mutatott, azonban az utolsó mérés alkalmával már csak a beöntözött állományra igaz ez az állítás.

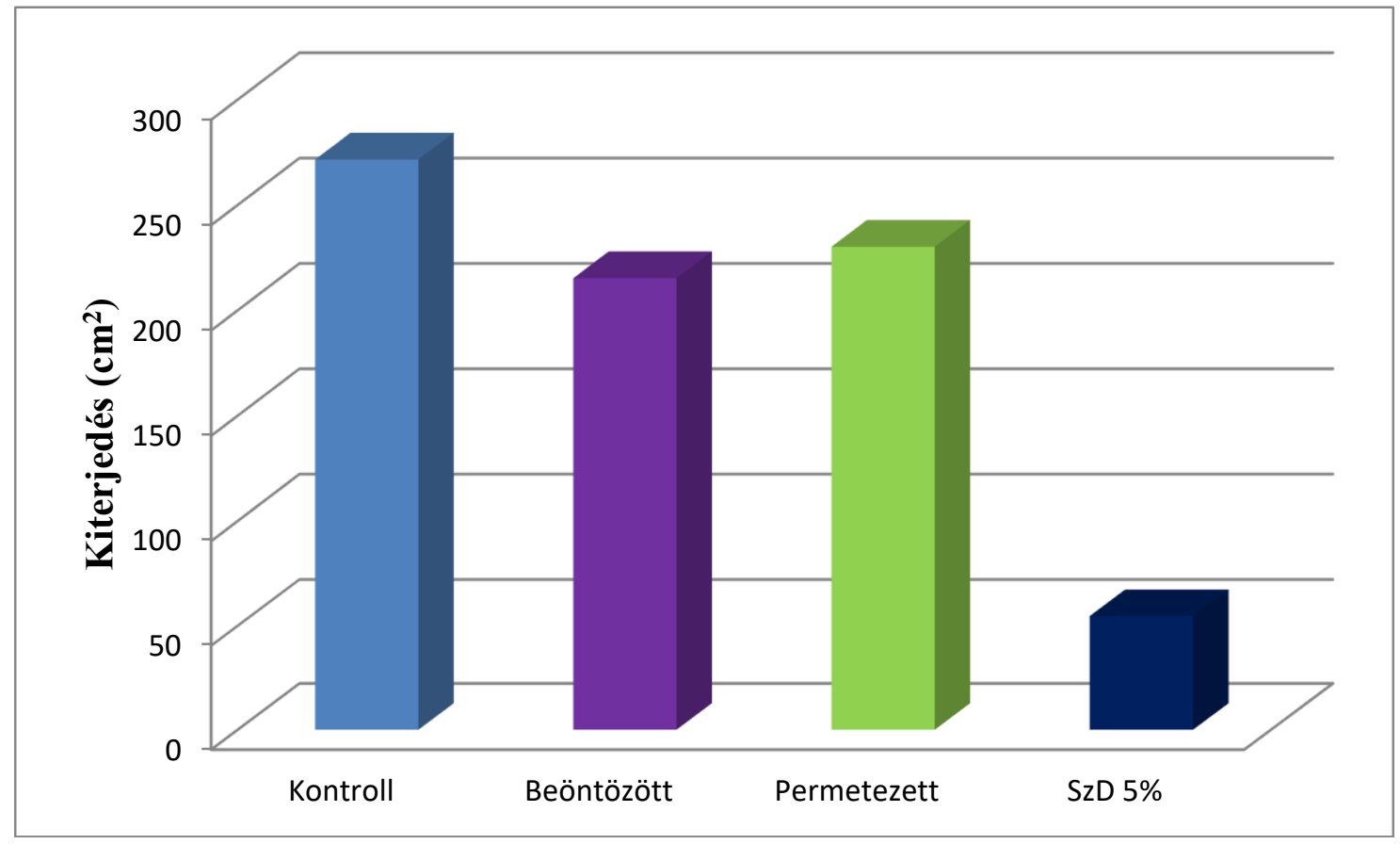

4. ábra. Kendal biostimulátor hatása a Delta fajtasorozat 'All Colors Mix' fajta átlagos kiterjedésére (Kecskemét, 2019. 03. 13.)

\subsection{Biostimulátor hatása a Delta fajtasorozat 'All Colors Mix' fajta átlagos virágbimbó számára}

Az átlagos virágbimbószám alakulása szempontjából a kapott eredmények alapján jól láthatjuk, hogy nem lehet konkrét következtetéseket levonni, hogy melyik kezelés bizonyult a legkedvezőbbnek, ugyanis a hetente történő mérések alkalmával folyamatos változás történt (5. ábra). Az utolsó mérés alkalmával a kontroll és a beöntözött állomány azonos átlagos virágbimbó számot ért el, a legkevesebb virágbimbó a permetezett állomány esetében fejlödött. $\mathrm{A}$ varianciaanalízissel történő kiértékelés során megállapítottuk, hogy a három kezelés egyike között sem alakult ki szignifikáns különbség. 


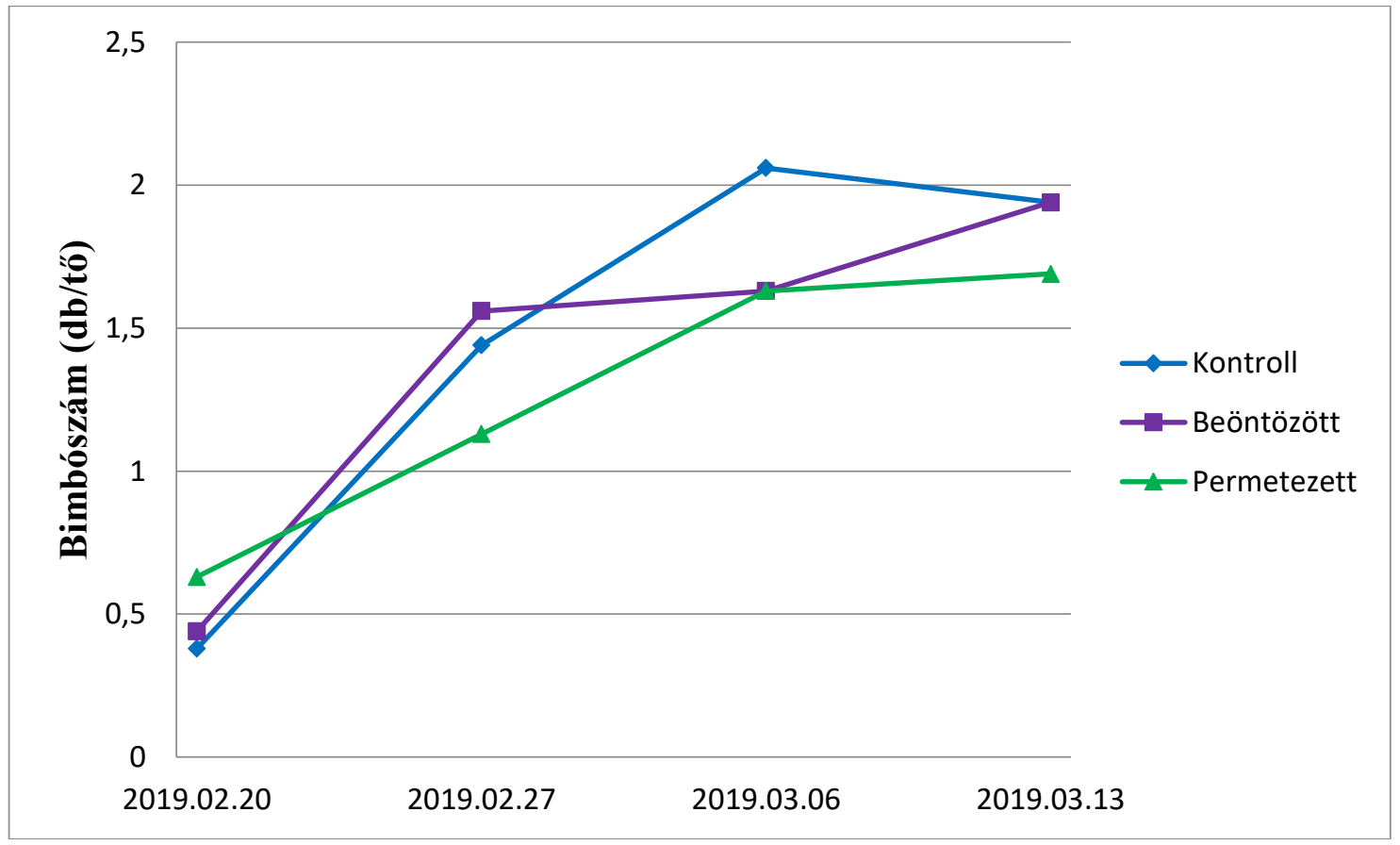

5. ábra. Kendal biostimulátor hatása a Delta fajtasorozat 'All Colors Mix' fajta átlagos virágbimbó számára

\subsection{Biostimulátor hatása a Delta fajtasorozat 'All Colors Mix' fajta átlagos virágszámára}

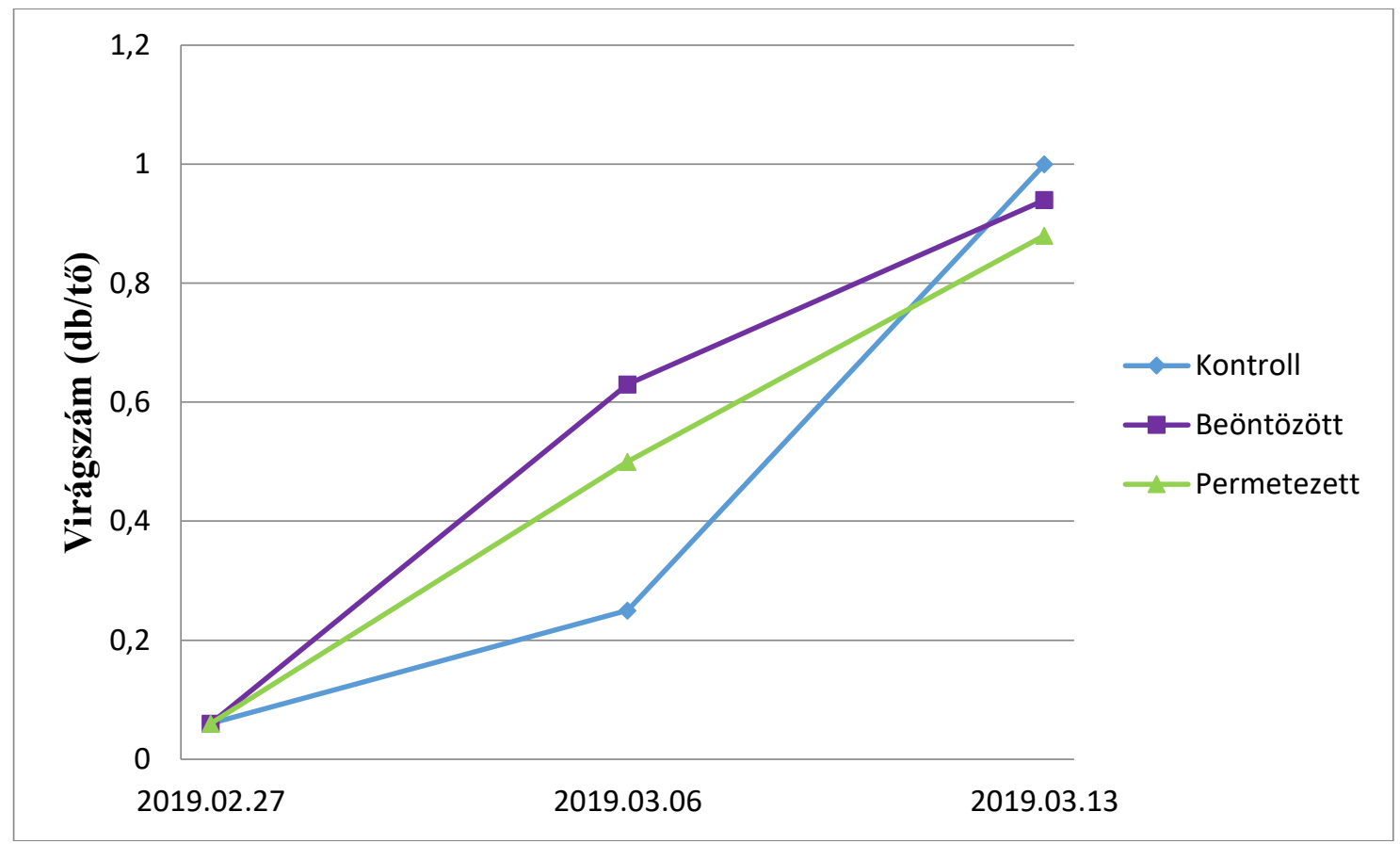

6. ábra. Kendal biostimulátor hatása a Delta fajtasorozat 'All Colors Mix' fajta átlagos virágszámára

A virágszám szempontjából a virágbimbószámhoz hasonlóan, szintén nem lehet konkrétumokat megfogalmazni, hogy melyik kezelés bizonyult a legkedvezőbbnek, folyamatos változás tapasztalható a kezelések között, azonban az értékesítés elött álló növények közül a legkedvezőbbnek a kontroll állomány bizonyult (6. ábra). Elmondhatjuk, hogy szignifikáns különbség az átlagos virágszám tekintetében nem alakult ki. 


\section{Következtetések}

A Kendal biostimulátor alkalmazásával az elsődleges célunk az volt, hogy a palántanevelés befejeztével minél alacsonyabb, kompakt habitussal, sok virággal és bimbóval rendelkező, piacos növényeket kapjunk.

A növénymagasság tekintetében a Viola $x$ wittrockiana Delta fajtasorozatba tartozó 'All Colors Mix' színkeverék fajta esetében a beöntözött kezelés érte el a kívánt hatást, a legmagasabb növénymagasságot a kezeletlen állománynál kaptuk.

A növények kiterjedése tekintetében az 'All Colors Mix' színkeverék fajta esetében a már értékesítésre kész növények esetében a kontroll állomány szignifikánsan nagyobb kiterjedéssel rendelkezett a beöntözött kezeléshez képest. A legkisebb habitussal a beöntözött állomány egyedei rendelkeztek, míg a legbokrosabb habitust a kontroll állomány produkálta.

Elmondhatjuk, hogy a növények termetére (magasságára, kiterjedésére) pozitívan hatott a beöntözéses kijuttatási mód a permetezéssel szemben. A beöntözéssel csökkenthető a készítmény kijuttatási vesztesége (kisebb mennyiségü lesz a feleslegben, a növény környékére kipermetezett anyag, valamint az esetleges elpárolgás mértéke is alacsonyabb). A kedvezően kisebb méretü növények szállítása könnyebb, ráadásul egységnyi területen többet lehet nevelni belölük, ezért ajánlott a biostimulátor beöntözéssel történő kijuttatása.

Virágbimbó szám tekintetében az 'All Colors Mix' színkeverék fajta esetében a beöntözött kezelés bizonyult a legkedvezőbbnek, a legkevesebb virágbimbószámot a permetezett kezelés eredményezte.

Az 'All Colors Mix' színkeverék fajta esetében a növények virágszámának alakulása a virágbimbószámhoz hasonlóan alakult. A beöntözött kezelés bizonyult a kedvezőbbnek a permetezett kezeléshez képest, értékesítés előtt azonban a kontroll állomány átlagos virágszáma lett a legmagasabb. A kontroll csoportban tapasztalt több virág voltaképpen nem jelent előnyt a kezelt állományokhoz képest, ugyanis az árvácska virága puha, sérülékeny, ezért a sok virág hátrányt is jelenthet, nem csak szállításkor, de a kiültetéskor is.

Összességében megállapíthatjuk, hogy a Kendal beöntözéssel történő kijuttatása kedvezően hatott a Delta 'All Colors Mix' fajta díszítőértékére.

\section{Köszönetnyilvánítás}

Köszönettel tartozunk a kutatás támogatásáért, amely az EFOP-3.6.1-16-2016-00006 „A kutatási potenciál fejlesztése és bővítése a Neumann János Egyetemen" pályázat keretében valósult meg. A projekt a Magyar Állam és az Európai Unió támogatásával, az Európai Szociális Alap társfinanszírozásával, a Széchenyi 2020 program keretében valósul meg.

\section{Irodalomjegyzék}

[1] http://www.plantalliance.hu

[2] Udvardy, L.: A Kertészeti Növénytan. Növényismereti kompendiuma. SZIE Kertészettudományi Kar, Budapest, 2002.

[3] Lévai, P.: Dísznövénytermesztés, KF Kertészeti Főiskolai Kar, Kecskemét, 2000.

[4] Schmidt, G.: Növényházi dísznövények termesztése, Mezőgazda Kiadó, Budapest, 2002. pp. 614-620

[5] http://www.floretum.hu

[6] http://www.syngenta.de

[7] http://www.plantsoftheworldonline.org

[8] Hessayon, D. G.: Virágágyi dísznövények, Park Könyvkiadó, Budapest, 1997.

[9] Merényi, A.: Árvácska egyszeregy. Kertészet és Szőlészet, 2011. 60. évf. (44. sz.) pp. 9.

[10] Honfi, P. - Tillyné, M. A.: Korszerü kertészet Modern dísznövénytermesztés és - kereskedelem, Budapesti Corvinus Egyetem, 2011. ISBN: 978-963-503-537

[11] Merényi, A.: Árvácska gazdaságosan. Kertészet és Szőlészet, 2006. 55. évf. (38. sz.) pp. 16.

[12] Pap, E.: Kapuvári árvácskák. Kertészet és Szőlészet, 2006. 55. évf. (35. sz.) pp. 18-19.

[13] Merényi, A.: Árvácska-arculatváltás. Kertészet és Szőlészet, 2015. 64. évf. (13. sz.) pp. 21-23.

[14] http://www.icl-sf.hu

[15] Janicka, D. - Dobrowolska A.: Effect of organic media on growth and development of Patiola F1 horned violet (Viola cornuta L.). ACTA AGROBOTANICA, Vol. 66 (1), 2013: 95-104. DOI: 10.5586/aa.2013.011

[16] Vargáné, N. A.: Biostimulátorok. Kertészet és Szőlészet, 2016. 65. évf. (15. sz.) pp. 12. 
[17] Anonym,: A biostimulátorok létjogosultsága a modern mezőgazdaságban. Agrofórum, 2018. a. 29. évf. (2. sz.) pp. 164-165.

[18] Anonym,: Minőség és fejlődés = MALAGROW, Biostimulátorok a pályán. Agrofórum extra, 2018. b. (75. sz.) pp. 150.

[19] http://www.malagrow.hu

[20] Malagrow,: Megoldások könyve, Malagrow Kft., Szolnok, 2017. 